\title{
Research on Talent Cultivation Strategy of Adult Universities under the Background of "Mass Entrepreneurship and Innovation"
}

\author{
Qiangqiang Zhou \\ Zhejiang Open University, Hangzhou, China \\ Email: zhouqq@zjtvu.edu.cn
}

How to cite this paper: Zhou, Q. Q. (2019). Research on Talent Cultivation Strategy of Adult Universities under the Background of "Mass Entrepreneurship and Innovation". Creative Education, 10, 3392-3401.

https://doi.org/10.4236/ce.2019.1013261

Received: November 28, 2019

Accepted: December 17, 2019

Published: December 20, 2019

Copyright $\odot 2019$ by author(s) and Scientific Research Publishing Inc. This work is licensed under the Creative Commons Attribution International License (CC BY 4.0).

http://creativecommons.org/licenses/by/4.0/

\begin{abstract}
As a new educational concept and practice, innovation and entrepreneurship education has attracted enough attention in global adult colleges and universities. Strengthening innovation and entrepreneurship education and training innovation and entrepreneurship talents are the new requirements of innovation and development for the country's innovation construction, the realistic choice of innovation for traditional education and accelerating the reform and development of adult colleges and universities, the inevitable requirement of improving the quality of graduates, and the promotion of College Students' integration into the tide of "mass entrepreneurship and innovation". Starting from the analysis of the current situation of innovation and entrepreneurship education in colleges and universities, based on the era background of "mass entrepreneurship, mass innovation", taking the cultivation of "mass entrepreneurship and innovation" as the goal, this paper discusses the construction method of innovation and entrepreneurship curriculum system with ability as the core, students as the main body and market as the guide, and puts forward that it is necessary to update the educational concept, correctly position the training goal, and formulate and improve the entrepreneurship curriculum. We should reform the talent evaluation system of adult colleges and universities, strengthen the power of entrepreneurship and innovation mentors, and strengthen the cooperation between schools and enterprises. We should innovate the talent training mode of "mass entrepreneurship and innovation" in adult colleges and universities, put forward proposals for the implementation of the new talent training mode of "mass entrepreneurship and innovation" in adult colleges and universities, and provide theoretical support for the cultivation of "mass entrepreneurship and innovation" talents in adult colleges and universities.
\end{abstract}




\section{Keywords}

Innovation and Entrepreneurship, Adult Universities, Personnel Training

\section{Introduction}

The era background of "mass entrepreneurship, mass innovation" puts forward new requirements for innovative and entrepreneurial talents. The cultivation of "mass entrepreneurship and innovation" talents is an important measure for the country to realize "mass entrepreneurship and innovation". Adult higher education is a parallel educational activity with formal education, which should play its unique advantages in the cultivation of innovative talents. The "mass entrepreneurship and innovation" education is oriented to all adult higher education students, and the "mass entrepreneurship and innovation" education is integrated into the whole process of adult higher education personnel training (Raposo \& Paco, 2011). "Entrepreneurship and innovation" education should be combined with professional education, highlight the core of entrepreneurship and innovation education, take the reform of curriculum system as a means, focus on the reform of talent training mode, and constantly promote the "entrepreneurship and innovation" work of adult colleges and Universities Serving the country, so as to train more and better innovative talents for the country.

\section{Theoretical Basis of Innovation and Entrepreneurship Education}

Colin bor, an expert of the world organization for economic cooperation and development, first proposed entrepreneurship education. He pointed out that people in the future should have three "education passports", that is, academic "passports", professional "passports", and "passports" to prove one's ambition and pioneering ability (Ye, 2009). In 1989, UNESCO officially put forward that the education of enterprising spirit and pioneering skills is the "innovation and entrepreneurship education” advocated by China (Zhang, 2007). China’s entrepreneurship education began in the "Tsinghua University Entrepreneurship plan competition" in 1997, and now it has only a decade of history. In 2002, a number of schools were selected as pilot schools for entrepreneurship education in China. However, innovation education has not formed an independent education system, and innovation and entrepreneurship education will gradually be integrated.

In recent years, the innovation and entrepreneurship education in Chinese Adult Colleges and universities has been continuously strengthened and integrated with interdisciplinary and cross learning stages. Based on the integration of professional characteristics and innovation and entrepreneurship resources, we have actively explored and achieved certain results (Guo, 2011). However, there are still some problems in the innovation and entrepreneurship education, 
such as the lack of close integration with professional education, and the lack of good links with practical activities; the lack of awareness of innovation and entrepreneurship education in the process of education, the single teaching method, and the weak effect in the process of "mass entrepreneurship and innovation" practice; the lack of practice innovation and entrepreneurship platform, and the lack of the concept of innovation and entrepreneurship education. The real integration with the school's teaching system has not formed a new model of innovative entrepreneurship education that integrates the comprehensive reform of teaching and personnel training. At the same time, the orientation of innovation and entrepreneurship education is not accurate. Adult colleges and universities do not recognize the essence of innovation and entrepreneurship, only pay attention to the training of students' knowledge and skills, and do not cultivate students' awareness and ability of innovation and entrepreneurship. They do not combine the theoretical courses of innovation and entrepreneurship education with talent training programs better, and do not make systematic regulations on innovation and entrepreneurship courses Plan: Entrepreneurship Education Curriculum and professional curriculum, interdisciplinary and professional cross, teaching and scientific research practice are not perfectly combined, which does not make entrepreneurship education and teaching system better integrated; entrepreneurship education is not necessarily connected with subject teaching and professional education; entrepreneurship theory curriculum and practice curriculum have not formed a more systematic and scientific mode (Katz, 2003).

The relevant entrepreneurship courses offered by adult colleges and universities do not have unified and scientific regulations on the teaching objectives, lack of systematicness in the curriculum of entrepreneurship education, and do not integrate the curriculum and specialty of innovation and entrepreneurship; the innovation education and entrepreneurship education are separated, and the innovation and entrepreneurship education and professional education are not connected; the innovation and entrepreneurship education does not have enough practical education platform to support it. The integration of social resources is not enough; the main body of promoting the cultivation of innovative and entrepreneurial talents is not clear, and the rights and responsibilities are not clear; the way of innovation and entrepreneurship education in Colleges and universities is single, mostly in the form of "career planning", "Challenge Cup" and other competitions. The evaluation system of innovation and entrepreneurship is not perfect, and the training effect of innovation and entrepreneurship talents is not scientifically defined; there is a lack of professional teachers in innovation and entrepreneurship; the curriculum form is single, and the teaching method is more traditional, and the curriculum deviates from the needs of social development (Bonnici, 2003). It only pays attention to the theoretical teaching, but ignores the practical teaching, and cannot cultivate real innovation talents. 


\section{Main Problems of Innovation and Entrepreneurship Education in Adult Colleges and Universities}

At present, China's adult education is in a dilemma. How to create the atmosphere of adult students' innovation and entrepreneurship, stimulate the potential of innovation and entrepreneurship, improve the skills of innovation and entrepreneurship, and finally rely on the power of innovation and entrepreneurship to reverse the plight of adult education is a problem in front of us.

1) Lagging behind in the construction of innovation and entrepreneurship education curriculum system

Although colleges and universities set up adult innovation and entrepreneurship work leading institutions with school leaders as the group leaders, secondary departments and adult education colleges as the influence, they cannot integrate innovation and entrepreneurship resources in the specific implementation process of adult education to form a joint force of innovation and entrepreneurship education. Some colleges and universities still pay attention to the work idea of full-time ordinary students' innovation and entrepreneurship education. Adult students' innovation and entrepreneurship education stays in the form of organization, and adult education colleges are assigned to take the lead, unable to give full support in policy, capital and logistics support, and there are such phenomena as inaction and two layers of skin. At the same time, it still exists in the process of adult students' innovation and entrepreneurship curriculum system construction (Roberts, Murray, \& Kim, 2017). There are a series of problems in the course category, such as the main way of online teaching, the teaching process of teaching knowledge according to the book, the lack of talents of full-time adult education innovation and entrepreneurship teachers, and the difficulty of credit recognition of the course system, which cannot form the organic combination of adult students' innovation and entrepreneurship theory teaching and innovation and entrepreneurship practice activities.

2) The innovation and entrepreneurship investment and financing channels are not smooth enough

There are four kinds of financing channels for adult students' innovation and Entrepreneurship: bank policy loan, government special fund for entrepreneurship, venture capital and self financing. From the perspective of adult students' choice of financing channels, self financing funds are affected by economic conditions and other factors, venture capital requires high maturity and feasibility of the project, and adult students' financing mainly depends on bank policy loans and government special funds for entrepreneurship. However, in practice, the bank's policy loans require adult students to provide mortgage certificates, repayment ability certificates and family income related materials, which makes it more difficult to obtain financial support. However, due to the impact of the identity of adult students, the government's special funds for entrepreneurship vary greatly in terms of capital assistance, number and ratio of projects, which makes the financing channels for adult students' innovation and entrepreneur- 
ship blocked.

3) The school enterprise cooperation is not close enough, and the success rate of innovation and entrepreneurship is not high

At present, colleges and universities have basically established their own innovation and entrepreneurship incubation parks and school enterprise cooperation bases, but due to the constraints of capital investment, patent transfer and project dividend, the basis of cooperation is relatively weak. Most university enterprise cooperation mechanisms are still at the initial stage of development, such as inviting entrepreneurs to give lectures, visiting alumni enterprises and hiring outside business mentors. These ways lead to small space, low profit and slow effectiveness of the cooperation between enterprises and universities. In addition, there are few ways in university enterprise cooperation, such as enterprise capital injection, new technology investment and venture capital establishment, which further leads to the low success rate of adult students' innovation and entrepreneurship.

4) Lack of perfect guarantee system for innovation and Entrepreneurship

There are nine factors to measure the environmental conditions of innovation and Entrepreneurship: financial support, government policies, government projects, education and training, research and development transfer, business environment, market openness, physical infrastructure, culture and social norms. China's overall environment for innovation and entrepreneurship is gradually improving. The central and local governments have successively issued policies to support full-time ordinary college students' innovation and entrepreneurship, and given special care in tax, endowment insurance, personnel system and market informatization (Potter, 2008). However, in the process of adult students' innovation and entrepreneurship, they tend to be affected by their own identity, academic degree, social recognition and other adverse factors, which cause the failure of innovation and entrepreneurship Fair treatment and project losses often occur, and the supporting emergency measures, compensation programs and security systems are not perfect. How to improve the entrepreneurial environment and enhance the performance of innovation and entrepreneurship, and how to ensure the effectiveness, rationalization and profitability of adult students is a serious problem faced by colleges and universities.

\section{Promotion Strategy of "Mass Entrepreneurship and Innovation" Talent Training Mode in Adult Colleges and Universities}

1) Update education concept and create a good atmosphere for innovation and Entrepreneurship

With the development of entrepreneurial economy, the demand for talents with entrepreneurial quality and entrepreneurial spirit has increased sharply. However, the traditional education, which grows in the planned economy, pays more attention to knowledge than ability, theory than practice, memory than 
thinking, indoctrination than creation, obviously can not meet the demand of social development for talents. Influenced by the traditional education concept, college graduates most value "iron rice bowl" after 70 and "stability" after 80 in their employment choice. However, they lack due attention to the independent entrepreneurship advocated by the state. The main reason is the lack of innovation and entrepreneurship education. According to the survey, the entrepreneurship rate of college graduates in China is less than 3\%, and that in Europe and America has reached 30\% - 40\%. In the United States, nearly 53\% of teenagers hope to start their own businesses one day. According to the big data report on the graduation destination of 2018 college graduates in China, 19\% of them aspire to start their own businesses and become bosses (Amabile, 1997). Therefore, it is necessary to update the education concept, create a social environment suitable for innovation and entrepreneurship, cooperate with the government, enterprises and schools, optimize the entrepreneurship policy support and reduce the threshold of entrepreneurship; reform the education and teaching mode, explore the innovation and entrepreneurship practice platform; break the barriers of exam oriented Education, establish a new outlook on talents, pay attention to the cultivation of entrepreneurship awareness and entrepreneurship skills of learners, so as to help learners Innovation and entrepreneurship activities provide technical and venue support. Enterprises should also open up a wide range of ways to facilitate the practical training of learners; successful entrepreneurs show their own experience and regularly hold special lectures on innovation and entrepreneurship for learners, so as to infect learners with their own entrepreneurial experience and stimulate their entrepreneurial enthusiasm. The mass media increased the model publicity of the success of entrepreneurship, so that innovation and entrepreneurship are deeply rooted in the hearts of the people (Mei \& Xu, 2009).

2) Correctly positioning the talent training objectives of Adult Higher Education

With the adjustment of economic structure and industrial structure, some new occupations and posts have emerged in the society. The "iron rice bowl" has been broken, and any practitioners are likely to lose their jobs, and then face the re-employment and entrepreneurship. The demand of the society for talents is more diversified. The traditional adult higher education pays more attention to the education of academic compensation. The design of talent training program has a strong color of general higher education. The training objective is single, the teaching content focuses on the teaching of theoretical knowledge, and despises the training of practical ability. It is divorced from the actual situation of adult learners' job, and the trained talents are difficult to adapt to the needs of social development. In order to carry out the innovation and entrepreneurship education, we must reform the talent training program of adult higher education, reasonably locate the talent training goal of adult higher education, face the social demand and base on the development of the industry. In terms of the design of training objectives and the formulation of personnel training specifica- 
tions, we should follow the guiding spirit of serving the needs of social and economic development and meeting the needs of practitioners' self-development, and take the training of post and occupation comprehensive ability as the leading role, so as to cultivate the all-round development, innovative ability and occupation adaptability, application-oriented and skill oriented professionals serving the production and management line for the society.

3) Formulate and improve entrepreneurship courses

The realization of the goal of talent training is inseparable from the implementation of curriculum, so we must set up reasonable curriculum according to the needs of social development and the learning characteristics of adult learners. First of all, it is necessary to broaden the horizontal connection between the majors and realize the infiltration and intersection between the liberal arts and science courses. There are not only public courses, professional basic courses, professional expansion courses, but also a certain proportion of practical courses. It is necessary to pay attention to the comprehensiveness, practicality and experience of the course content, enhance the initiative of students' self-study, and cultivate students' comprehensive ability. Secondly, different innovation and entrepreneurship courses are set up for different majors, such as entrepreneurship education, successful entrepreneurship case analysis, innovation thinking training, etc., so as to train the innovation and entrepreneurship ability of learners. Once again, most adult learners are on-the-job practitioners. The selection and setting of innovation and entrepreneurship courses must be combined with the learning characteristics of adult learners. In addition to the independent entrepreneurship content of "another mountain" after job hopping and leaving, more attention should be paid to the "internal entrepreneurship" of practitioners in the enterprise. In the course setting, some new achievements and new technologies of the industry should be introduced to actively transform new knowledge into courses Let's encourage learners' entrepreneurial intention, guide learners to actively undertake internal business and $\mathrm{R} \& \mathrm{D}$ projects in combination with their majors, improve their professional skills and make profits for enterprises, so as to realize their personal value.

4) Explore and reform the education evaluation system

Premier Li Keqiang pointed out that mass entrepreneurship and innovation are conducive to the adjustment of China's economic structure and the enhancement of new driving forces for development, and are important ways to achieve national prosperity and people's prosperity. To promote mass entrepreneurship and innovation "can not only expand employment and increase residents' income, but also promote vertical social mobility and fairness and justice". Adult higher education should keep up with the pace of the times, meet the learning needs of different learners around the needs of social development, and cultivate the innovation and entrepreneurship ability of learners. The traditional adult higher education mainly imparts theoretical knowledge, takes examination results as the only basis for evaluation, neglects the cultivation of students' inde- 
pendent learning ability and critical spirit, which leads to the deficiency of learners' innovation awareness and practical ability (Walter \& Block, 2016). In order to carry out the education of innovation and entrepreneurship, we must change the educational concept and reform the evaluation system. We should not only investigate the knowledge mastery of learners, but also the practical ability of learners to use knowledge to analyze and solve problems. In terms of assessment methods, there are not only closed book examinations, but also investigation reports, small papers, business practice, etc. especially for some entrepreneurship courses, we can boldly try some new evaluation modes, such as for some successful "makers", the winners in the innovation competition can directly obtain entrepreneurship course credits.

5) Strengthen the construction of entrepreneurial and innovative teachers

The implementation of innovation and entrepreneurship education can not be separated from the intellectual support of teachers. The traditional teachers in adult colleges and universities generally lack the practical experience of production line and entrepreneurship activities, mostly from theory to theory, which makes innovation and entrepreneurship education become a mere formality, which is not conducive to the cultivation of learners' innovation and entrepreneurship ability, but also strikes learners' interest in learning. Therefore, in order to do a good job in innovation and entrepreneurship education, adult colleges and universities must strengthen the construction of "double teacher" teaching staff. Schools should open their doors to run schools (Guo, Liu, \& Lu, 2008). On the one hand, they should hire some industry backbones and experts to teach, such as experienced engineers, accountants, lawyers, successful makers, etc. On the other hand, teachers are encouraged to exchange and study in the practice base of school enterprise cooperation to enrich their practical experience. At the same time, the school should encourage teachers to start their own businesses, so that teachers can accumulate perceptual experience in entrepreneurial practice and improve their entrepreneurial ability.

6) Strengthen cooperation between schools and enterprises to jointly cultivate "mass entrepreneurship and innovation" students

One of the training objectives of adult higher education is to provide enterprises and institutions with "well used and well retained" skilled talents. Therefore, the university should adhere to the concept of talent training with service as its purpose and employment as its orientation, improve the vocational ability of students, cultivate the vocational elements of students, strengthen practical teaching, take the road of talent training with the combination of work and learning, and school enterprise cooperation, and put teaching into practice Education is closely linked with the development of social economy, and a stable cooperation agreement of off campus practice base is established to allow students to practice with pay and on-the-job, strengthen professional skills in work and improve the level of practice and operation (Stamboulis \& Barlas, 2014). At the same time, it can alleviate the urgent need of talents in the peak season of the 
enterprise, obtain economic benefits for the enterprise, and realize the mutual benefit and win-win between the University and the enterprise. The specific ways of implementation can be practical and flexible. First, actively encourage teachers to join the company for training and accumulate practical experience; second, invite the company to enter the campus, find out the common interests of the school and the company, introduce the enterprise's equipment, management, business, culture, etc. into the school, students directly participate in the whole process of enterprise production management, realize the "zero distance" training of theoretical knowledge and practical ability; third, bring students into the enterprise, depending on the site and equipment of the enterprise, the school moves the classroom to the workshop. On the one hand, it can solve the problem of insufficient practice teaching site in the school. On the other hand, it can provide continuing education and training for the employees of the enterprise and provide intellectual support for the sustainable development of the enterprise. On the other hand, it can carry out expert lectures. On the one hand, it can hire entrepreneurs and industry experts with rich practical knowledge to give lectures in the school. Some of the new technologies, achievements and techniques of the industry development are brought to the school to broaden the students' horizons.

\section{Conclusion}

It is of great historical significance and function for adult colleges and universities to carry out entrepreneurship education for adult college students. It is an inevitable choice for adult colleges and universities to actively adapt to the economic and social development in the new era and an effective way for the sustainable development of adult higher education. Adult colleges and universities are still in the exploration stage in the research and practice of entrepreneurship education, and the theoretical support and model construction are not mature enough. The model of entrepreneurship education discussed in this paper is based on the current ideas and ideas of adult higher education reform. In my opinion, at present and in a certain period in the future, adult colleges and universities should stand at the forefront of the times, follow the main theme of the national economic and social development trend, take the cultivation of entrepreneurial talents as a breakthrough, actively change the educational concept, increase the strength, breadth and depth of school enterprise cooperation, dare to practice the new entrepreneurial education mode, and reflect their own characteristics, so the entrepreneurial education of adult colleges and universities will be To make a breakthrough. The school enterprise cooperative entrepreneurship education model will certainly open up a new world for the future development of adult colleges and universities.

\section{Acknowledgements}

This paper was supported by the general scientific research project of Zhejiang 
Provincial Department of education in 2019: "Research on innovation of mass entrepreneurship and innovation talent training mechanism in adult colleges and universities from the perspective of paradigm" (Project No.: Y201941726); Higher education reform project of Zhejiang Open University in 2019: "Research on talent training mode in adult colleges and Universities under the background of mass entrepreneurship and mass innovation" (Project No.: XJG201907).

\section{Conflicts of Interest}

The author declares no conflicts of interest regarding the publication of this paper.

\section{References}

Amabile, T. M. (1997). Motivating Creativity in Organizations: On Doing What You Love and Loving What You Do. California Management Review, 40, 39-58. https://doi.org/10.2307/41165921

Bonnici, L. J. (2016). The End of College: Creating the Future of Learning and the University of Everywhere. Journal of Education for Library and Information Science, 3, 249.

Guo, L. J., Liu, Q., \& Lu, X. Y. (2008). Comparative Analysis of Entrepreneurship Education Policies of Chinese and Foreign University Students. Higher Education Exploration, No. 1, 132-135.

Guo, L. Z. (2011). Analysis of the Current Situation of Entrepreneurship Curriculum in Colleges and Universities in China. Modern Education Science, No. 9, 28-33.

Katz, J. A. (2003). The Chronology and Intellectual Trajectory of American Entrepreneurship Education: 1876-1999. Journal of Business Venturing, 2, 283-300. https://doi.org/10.1016/s0883-9026(02)00098-8

Mei, W. H., \& Xu, X. Z. (2009). Problems and Strategies in the Development of Entrepreneurship Education in Chinese Universities. Education Research, No. 4, 67-72.

Potter, J. (2008). Entrepreneurship and Higher Education: Future Policy Directions. Sourced Education \& Skills, 2008, 422-448.

Raposo, M., \& Paco, A. (2011). Entrepreneurship Education: Relationship between Education and Entrepreneurial Activity. Psicothema, 23, 453-457.

Roberts, E. B., Murray, F., \& Kim, J. D. (2017). Entrepreneurship and Innovation at MIT: Continuing Global Growth and Impact.

http://web.mit.edu/innovate/entrepreneurship2015.pdf

Stamboulis, Y., \& Barlas, A. (2014). Entrepreneurship Education Impact on Student Attitudes. International Journal of Management Education, 12, 365-373. https://doi.org/10.1016/j.ijme.2014.07.001

Walter, S. G., \& Block, J. H. (2016). Outcomes of Entrepreneurship Education: An Institutional Perspective. Journal of Business Venturing, 31, 216-233.

Ye, Y. H. (2009). A Study on the Influencing Factors of College Students' Entrepreneurial Intention. Education Research, No. 4, 73-77.

Zhang, T. (2007). A Study of Timmons' Entrepreneurship Education Thoughts. Contemporary Education Forum (Principal Education Research), No. 6, 51-53. 